\title{
The Effect of Obesity on Pain Severity and Pain Interference
}

Jade Basem, B.A. ${ }^{\dagger}$, Robert S. White, M.D. ${ }^{+}$, Stephanie A. Chen, M.D. ${ }^{\ddagger}$, Elizabeth Mauer, M.S. ${ }^{\S}$, Michele L. Steinkamp, R.N. ${ }^{+}$, Charles E. Inturrisi, Ph.D. ${ }^{\perp}$ Lisa Witkin, M.D. ${ }^{+}$

\section{From the}

†Department of Anesthesiology, Weill Cornell Medicine, New York, NY

$\ddagger$ Department of Anesthesiology, Columbia University Medical Center, New York, NY

$\S$ Department of Healthcare Policy \& Research, Weill Cornell Medicine, New York, NY

$\perp$ Department of Pharmacology, Weill Cornell Medicine, New York, NY

\section{Address correspondence to:}

Lisa Witkin, MD, Department of Anesthesiology, Center for Comprehensive Spine Care at Weill Cornell Medicine, 240 East 59 ${ }^{\text {th }}$ Street, New York, NY 10022 (email:

lrw9003@med.cornell.edu)

\section{Conflicts of Interest:}

Charles Inturrisi receives compensation as described in a 2017 license agreement between

Charles E.. Inturrisi (and Paolo Manfredi) and Relmada Therapeutics, Inc.. for the development of compounds (including d-methadone) for the treatment of depression. Otherwise, the authors declare no conflicts of interest. 


\section{Funding:}

The authors have no sources of funding to declare for this manuscript.

\section{Ethical Approval Statement:}

This study was approved by the Institutional Review Board and Clinical Study Evaluation Committee of Weill Cornell Medicine. A full HIPAA waiver and full waiver of informed consent was requested as this study involved no more than minimal risk and was a retrospective chart review. The full HIPAA waiver and full waiver of informed consent was granted for all subjects.

\section{Running Head: Obesity, Pain Serverity, and Pain Interference}


medRxiv preprint doi: https://doi.org/10.1101/2020.03.02.20027425; this version posted March 3, 2020. The copyright holder for this preprint (which was not certified by peer review) is the author/funder, who has granted medRxiv a license to display the preprint in perpetuity.

All rights reserved. No reuse allowed without permission.

\section{ABSTRACT}

2 Background and objectives Obesity is one of the most prevalent comorbidities associated with

3 chronic pain, the experience of which can severely interfere with activities of daily living and

4 increase the utilization of clinical resources. Obesity is also a risk factor for increased pain

5 severity (pain intensity) and pain interference (pain related disability). We hypothesize that a

6 higher level of obesity, as measured by body mass index (BMI), would be associated with

7 increased levels of pain severity and interference in a population of chronic pain clinic patients.

8 Methods Participant data was pulled from a multi-site chronic pain outpatient database from

9 7/8/2011 to 10/17/2016. The Brief Pain Inventory (BPI), opioid prescriptions, and basic

10 demographic information were queried and we categorized participants into three different ordinal categories based on recorded BMI levels (underweight, normal and overweight, obese).

12 Bivariate analyses were performed to compare pain outcomes by BMI and by other demographic/clinical patient characteristics. Multivariable linear regressions were constructed to model each of four pain severity scores in addition to total pain interference score. All models examined BMI as the primary predictor, controlling for age, receipt of a pain procedure within 45 days prior to the pain clinic encounter, opioid prescription within 45 days prior to the encounter, and diagnosis. The total pain interference model additionally included pain severity

18 (as measured by worst pain in the past 24 hours) as a covariate.

Results 2509 patients were included in the study. The median BMI was 27 and the median age was 59 years. $77 \%$ of patients were diagnosed with musculoskeletal pain conditions. Bivariate tests revealed significant differences between BMI groups for all pain severity scores and for total pain interference score. On multivariable modelling controlling for age, pain procedure within 45 days prior to pain clinic encounter, opioid prescription with 45 days prior, and

24 diagnosis, obese patients had significantly higher pain severity (as measured by worst, least,

25 average, and current pain in the past 24 hours) as well as higher pain interference (as measured

26 by the overall pain interference score) than normal weight and overweight patients.

27 Conclusion In our study of pain clinic patients, obesity was found to be associated with

28 increased pain severity and pain interference. We believe that this relationship is multifactorial

29 and bidirectional. Pain phyisicans should consider the impact of obesity when addressing pain

30 management for patients. 


\section{INTRODUCTION}

32 The Institute of Medicine estimates that 100 million United States adults are affected by chronic pain, which costs the nation $\$ 635$ billion yearly in medical treatment and lost productivity ${ }^{1}$. Pain

34 is a common experience for the general population, as $11.2 \%$ of adults report daily pain symptoms ${ }^{2}$. Pain is the most common reason patients seek medical attention with approximately one-fifth of ambulatory medical care associated with pain as a primary symptom or diagnosis ${ }^{3 ; 4}$.

37 The experience of pain is complex, as chronic pain is a multidimensional hierarchical construct that consists of both the sensation of pain severity and interference in engagement with activities $^{5}$. In addition, a threshold effect occurs where low levels of pain intensity are not associated with functional interference; however, higher levels of pain intensity increase the probability of interference in a nonlinear fashion ${ }^{5-7}$.

43 One of the prevalent comorbidities that is commonly associated with chronic pain is obesity ${ }^{8}$.

44 Data from the National Health and Nutrition Examination Survey from 2015-2016 demonstrates that $39.8 \%$ of United States adults were obese ${ }^{9}$. The presence of obesity is associated with an

46 increase in self-reported bodily pain measures and pain related disability, a decrease in

47 psychological well-being, and reduced physical functioning ${ }^{10-12}$. The relationship between pain

48 and obesity is likely multi-directional and multi-factorial, including central pain and

49 inflammatory pathways ${ }^{13-15}$. Provider prescriptions of non-steroidal anti-inflammatory agents 50 used to treat pain are higher amongst obese patients ${ }^{16 ; 17}$.

52 Given the prevalence of obesity in the general and chronic pain populations and its effect on 53 clinical outcomes, it is important to understand how obesity affects the validated pain outcomes 
medRxiv preprint doi: https://doi.org/10.1101/2020.03.02.20027425; this version posted March 3, 2020. The copyright holder for this preprint (which was not certified by peer review) is the author/funder, who has granted medRxiv a license to display the preprint in perpetuity.

All rights reserved. No reuse allowed without permission.

54 commonly used in clinical practice, including pain severity and pain interference. Previous

55 research has elucidated higher pain scores in female, osteoarthritic, and postoperative patients

56 with obesity. However, these studies are often limited by small or homogeneous cohorts, or

57 examine outcomes that are not commonly used by chronic pain providers in a clinical setting ${ }^{18-}$

$58 \quad 22$. No major study to date has analyzed the impact that obesity has on pain severity and

59 interference scores in a general chronic pain population. Herein, we seek to further explore the

60 association of obesity as a risk factor for pain related outcomes. Outcomes of interest include:

61 pain severity and pain interference. We hypothesized that a higher level of obesity, as measured

62 by body mass index (BMI), would be associated with increased pain severity and pain

63 interference. 
medRxiv preprint doi: https://doi.org/10.1101/2020.03.02.20027425; this version posted March 3, 2020. The copyright holder for this preprint (which was not certified by peer review) is the author/funder, who has granted medRxiv a license to display the preprint in perpetuity.

All rights reserved. No reuse allowed without permission.

72

77

\section{METHODS}

\section{Patient Population}

We collected data from a longitudinal observational cohort of chronic pain outpatients seen in the Weill Cornell Medicine (WCM) pain medicine clinic from 7/8/2011 to 10/17/2016. These patients are part of a larger tri-institutional chronic pain database herein referred to as The Registry, which encompasses Pain Services data from WCM, Hospital for Special Surgery and Memorial Sloan-Kettering Cancer Center (MSKCC), New York, New York. The Registry design, enrollment procedures, data collection and analysis have been previously described ${ }^{23}$. A data sharing agreement exists between WCM and the Health System Innovation and Research Program, University of Utah School of Medicine, Salt Lake City, UT, who maintain the database and assist with the data analysis. Health System Innovation and Research Program merges the coded PRO data in Webcore with data captured in EPIC to form a complete coded limited data set for The Registry ${ }^{23}$. While patient identifiers are removed, the coded data contains encounter dates, and therefore the data represents a limited data set according to the HIPAA Privacy Rules. Patient data is collected under standard of care and is part of a quality improvement program.

The inclusion criteria for this study included all chronic pain patients, as defined by at least one clinic attendance. If multiple visit had data recorded, the first entry was the value used in analysis. The original exclusion criteria for The Registry was absence of a chronic pain diagnosis, but for this study the exclusion criteria also included patients without BMI data and without a specific type of chronic pain diagnosis for the encounter ${ }^{23}$. 
medRxiv preprint doi: https://doi.org/10.1101/2020.03.02.20027425; this version posted March 3, 2020. The copyright holder for this preprint (which was not certified by peer review) is the author/funder, who has granted medRxiv a license to display the preprint in perpetuity.

All rights reserved. No reuse allowed without permission.

87 Patient specific factors and process factors were obtained for each patient at each encounter.

88 These factors included: demographics (Age, Sex, Marital Status, Ethnicity, Language, Religion,

89 and Payor), vitals (height, weight, BP, Temperature, pulse rate), diagnoses, CPT codes,

90 medications, and the survey data which included the pain severity and pain interference scores.

91 BMI was calculated as weight in kilograms divided by the square of height in meters.

92 Participants were categorized into three groups based on BMI: underweight (BMI <18.5),

93 normal weight and overweight $(\mathrm{BMI}=18.5-29.9)$, and obese $(\mathrm{BMI} \geq 30)$; the normal weight

94 and overweight category was used as the reference in all models.

96 During each outpatient pain clinic encounter, pain information was collected using the Brief Pain

97 Inventory (BPI) short form. The BPI short form is a validated tool that assesses the presence of

98 pain; pain severity, pain interference, percentage of relief provided by pain treatments or

99 medications (0-100\%), and the location of pain at 22 pre-specified sites assessed over a 24-hour

100 recall period ${ }^{24}$. Patients describe their pain severity on a scale from 0 ("No Pain") to 10 ("Pain

101 as bad as you can imagine") when their pain is at its worst, least, on average, and if they are

102 experiencing pain right now ${ }^{7}$. Pain interference is measured on seven daily functions, including

103 general activity, mood, walking ability, normal work (includes both work outside the house and

104 housework), relations with other people, sleep, and enjoyment of life. Each pain interference

105 measure is assessed through a rating scale from 0 ("Does not Interfere") to 10 ("Completely

106 Interferes").

107

108

Estimating Opioid Use, Dosage, and Duration 
medRxiv preprint doi: https://doi.org/10.1101/2020.03.02.20027425; this version posted March 3, 2020. The copyright holder for this preprint (which was not certified by peer review) is the author/funder, who has granted medRxiv a license to display the preprint in perpetuity.

All rights reserved. No reuse allowed without permission.

109

110

Opioid medications that were being taken and prescribed at each encounter were abstracted from EPIC. For patients included in the Registry, we captured all the opioids recorded for each encounter backward to $11 / 1 / 2010$ (this date was specified as when clinicians were required to perform medication reconciliation in EPIC and therefore represents the most reliable data). Resultantly, opioid duration was measured from 11/1/2010 to 9/1/2016, including opioid use prior to entry into the Registry. Based on a discussion with the pain clinicians on patient opioid prescription filling practices, we looked back at least 45 days from their clinic visit for a schedule 2 opioid prescription or refill. We excluded patients receiving intrathecal opioids from this analysis.

\section{Statistical analysis}

Statistical analyses were performed using R Version 3.5.3 (Vienna, Austria) ${ }^{25}$. Bivariate analyses were performed to compare pain outcomes by demographic/clinical patient characteristics as well as to compare demographic/clinical patient characteristics by bmi groups (underweight, normal and overweight, and obese). Bivariate tests included independent two-sample t-tests, Analysis of Variance (ANOVA), or Chi-Squared/Fisher's Exact tests, as appropriate. Nonparametric equivalents were used for violations of normality.

To examine the effect of BMI on pain severity and pain interference we fit multivariable linear regression models to our data; regression coefficients along with their $95 \%$ confidence intervals were reported. We developed separate models for each of the four pain severity scores (worst, least, average, and current) and for total pain interference with the additional inclusion of pain severity as a covariate. All models adjusted for demographic and clinical variables available and 
medRxiv preprint doi: https://doi.org/10.1101/2020.03.02.20027425; this version posted March 3, 2020. The copyright holder for this preprint (which was not certified by peer review) is the author/funder, who has granted medRxiv a license to display the preprint in perpetuity. All rights reserved. No reuse allowed without permission.

132 considered relevant (age, pain procedure within 45 days prior, opioids prescribed within 45 days

133 prior, and diagnosis). All statistical tests were 2-sided with statistical significance assigned at an

134 alpha level of 0.05 . 
medRxiv preprint doi: https://doi.org/10.1101/2020.03.02.20027425; this version posted March 3, 2020. The copyright holder for this preprint (which was not certified by peer review) is the author/funder, who has granted medRxiv a license to display the preprint in perpetuity.

All rights reserved. No reuse allowed without permission.

\section{RESULTS}

A total of 2,509 patients were included in the study. The cohort's median age was 59 years, median BMI was $27 \mathrm{~kg} / \mathrm{m}^{2}$, and the most common pain diagnosis category was musculoskeletal pain $(77 \%)$. About $20 \%$ of the patients received a pain procedure within 45 days prior to the pain clinic encounter, and half of the patients (53\%) received an opioid prescription within 45 days prior. Differences between BMI groups are shown in Table 1. Some statistical significance represrents underlying differences in the spread of pain scores, as shown through the range. Bivariate tests revealed significant differences between BMI groups for all pain severity scores and for total pain interference score (Table 2).

For each multivariable model looking at pain severity (as either the worst, least, average, or current pain within the past 24 hours), obese patients demonstrated significantly higher scores than normal weight patients after controlling for age, pain procedure within the 45 days prior to the pain clinic encounter, opioid prescription within the 45 days prior, and diagnosis category. Specifically, obese patients had an average 0.354 higher severity score at their worst pain within the past 24 hours, 0.556 at their least pain within the past 24 hours, 0.382 at their average pain in the past 24 hours, and 0.625 at their current pain than normal weight patients. Similarly, for the multivariable model looking at overall pain interference, obese patients demonstrated significantly higher scores than normal weight patients after controlling for the same factors in addition to pain severity (as measured as the worst pain in the past 24 hours). Specifically, obese patients had an average 0.276 higher overall pain interference score than normal weight patients. 
medRxiv preprint doi: https://doi.org/10.1101/2020.03.02.20027425; this version posted March 3, 2020. The copyright holder for this preprint (which was not certified by peer review) is the author/funder, who has granted medRxiv a license to display the preprint in perpetuity.

All rights reserved. No reuse allowed without permission.

158 Confirming our assumption, pain severity (as measured as the worst pain in the past 24 hours)

159 was significantly associated with overall pain interference; specifically, overall pain interference

160 increased on average by 0.689 points for each additional point higher in worst pain severity. An

161 additional result of note is that underweight patients also showed a significant difference

162 compared to normal weight in the pain now severity model $(\mathrm{p}=0.033)$.

163

164 Opioid use was statistically significant for each pain severity and pain interference outcome used

165 in multivariable modeling ( $\mathrm{p}<0.0001$ for all outcomes). $58.3 \%$ of obese patients and $63.2 \%$ of

166 underweight patients were prescribed opioid medications within 45 days prior compared to only

$16750.7 \%$ of normal weight patients $(\mathrm{p}=0.001)$, with all BMI groups being more likely to take pain

168 medications than not. Differences between BMI groups also existed when looking specifically at

169 IR opioid medications and ER opioid medications prescribed. 56.3\% of obese patients and $61.8 \%$

170 of underweight patients were prescribed IR opioid medications compared to $47.4 \%$ of

171 normal/overweight patients $(\mathrm{p}<0.001)$. About $14 \%$ of both obese and normal/overweight

172 patients were prescribed ER opioid medications compared to $25 \%$ of underweight patients

$173(\mathrm{p}=0.041)$.

174

175

Table 1: Differences Between BMI Groups

\begin{tabular}{|c|c|c|c|c|c|}
\hline & $\mathrm{BMI}<18.5$ & BMI 18.5-29.99 & BMI $>=30$ & $p$ value & $\mathbf{N}$ \\
\hline Weight & $106[98.8 ; 118]$ & $154[135 ; 175]$ & $215[190 ; 243]$ & $<0.001$ & 2509 \\
\hline Height & $65.3[63.7 ; 69.0]$ & $66.0[63.0 ; 69.0]$ & $65.5[63.9 ; 69.0]$ & 0.163 & 2509 \\
\hline Age (continuous) & $52.2[36.8 ; 69.5]$ & $59.9[46.4 ; 71.7]$ & $59.9[49.4 ; 68.6]$ & 0.093 & 2509 \\
\hline Age (categorical) & & & & $<0.001$ & 2509 \\
\hline $18-44$ & $25(36.8 \%)$ & 401 (23.5\%) & $120(16.3 \%)$ & & \\
\hline $45-64$ & $23(33.8 \%)$ & $645(37.8 \%)$ & $364(49.6 \%)$ & & \\
\hline $65+$ & 20 (29.4\%) & 661 (38.7\%) & 250 (34.1\%) & & \\
\hline
\end{tabular}


medRxiv preprint doi: https://doi.org/10.1101/2020.03.02.20027425; this version posted March 3, 2020. The copyright holder for this preprint (which was not certified by peer review) is the author/funder, who has granted medRxiv a license to display the preprint in perpetuity. All rights reserved. No reuse allowed without permission.

Pain procedure with 45 days prior

\begin{tabular}{|c|c|c|c|c|c|}
\hline No & $57(83.8 \%)$ & $1366(80.0 \%)$ & $588(80.1 \%)$ & & \\
\hline Yes & $11(16.2 \%)$ & $341(20.0 \%)$ & $146(19.9 \%)$ & & \\
\hline Pain procedure with 45 days after & & & & 0.69 & 2509 \\
\hline No & $56(82.4 \%)$ & $1332(78.0 \%)$ & $576(78.5 \%)$ & & \\
\hline Yes & $12(17.6 \%)$ & $375(22.0 \%)$ & $158(21.5 \%)$ & & \\
\hline Opioid medication within 45 days prior & & & & 0.001 & 2509 \\
\hline No & $25(36.8 \%)$ & $841(49.3 \%)$ & $306(41.7 \%)$ & & \\
\hline Yes & $43(63.2 \%)$ & $866(50.7 \%)$ & $428(58.3 \%)$ & & \\
\hline IR opioid medications within 45 days prior & & & & $<0.001$ & 2509 \\
\hline No & $26(38.2 \%)$ & $898(52.6 \%)$ & $321(43.7 \%)$ & & \\
\hline Yes & $42(61.8 \%)$ & $809(47.4 \%)$ & $413(56.3 \%)$ & & \\
\hline ER opioid medications within 45 days prior & & & & 0.041 & 2509 \\
\hline No & $51(75.0 \%)$ & $1468(86.0 \%)$ & $627(85.4 \%)$ & & \\
\hline Yes & $17(25.0 \%)$ & $239(14.0 \%)$ & $107(14.6 \%)$ & & \\
\hline \multicolumn{6}{|l|}{ Pain Severity and Interference } \\
\hline Worst pain, 24 hours & $8.00[6.00 ; 9.00]$ & $8.00[6.00 ; 9.00]$ & $8.00[6.00 ; 9.00]$ & $<0.001$ & 2425 \\
\hline Least pain, 24 hours & $5.00[3.00 ; 7.00]$ & $4.00[2.00 ; 6.00]$ & $5.00[2.00 ; 7.00]$ & $<0.001$ & 2415 \\
\hline Average pain, 24 hours & $6.00[4.25 ; 8.00]$ & $6.00[4.00 ; 7.75]$ & $6.00[5.00 ; 8.00]$ & $<0.001$ & 2371 \\
\hline Pain now- current & $6.50[4.00 ; 8.00]$ & $5.00[3.00 ; 8.00]$ & $6.00[4.00 ; 8.00]$ & $<0.001$ & 2370 \\
\hline General Activity & $7.00[5.00 ; 9.00]$ & $6.00[4.00 ; 8.00]$ & $7.00[5.00 ; 9.00]$ & $<0.001$ & 2345 \\
\hline Mood & $7.00[4.00 ; 9.00]$ & $6.00[3.00 ; 8.00]$ & $6.00[3.00 ; 8.00]$ & 0.001 & 2330 \\
\hline Walking & $6.00[3.00 ; 9.00]$ & $5.00[2.00 ; 8.00]$ & $7.00[4.00 ; 9.00]$ & $<0.001$ & 2339 \\
\hline Normal work & $7.00[5.00 ; 9.00]$ & $6.00[4.00 ; 9.00]$ & $7.00[5.00 ; 9.00]$ & $<0.001$ & 2315 \\
\hline Relations with others & $5.00[1.25 ; 7.00]$ & $4.00[0.00 ; 7.00]$ & $5.00[0.00 ; 7.00]$ & 0.014 & 2294 \\
\hline Sleep & $6.50[3.00 ; 8.00]$ & $5.00[2.00 ; 8.00]$ & $6.00[3.00 ; 9.00]$ & 0.002 & 2318 \\
\hline Enjoyment of life & $8.00[5.00 ; 9.00]$ & $7.00[4.00 ; 8.00]$ & $7.00[5.00 ; 9.00]$ & $<0.001$ & 2297 \\
\hline Interference Total Score & $6.29[5.00 ; 7.71]$ & $5.57[3.29 ; 7.43]$ & $6.46[4.14 ; 8.00]$ & $<0.001$ & 2359 \\
\hline Diagnosis Category & & & & 0.001 & 2509 \\
\hline Musculoskeletal & $44(64.7 \%)$ & $1298(76.0 \%)$ & $578(78.7 \%)$ & & \\
\hline Neuropathic & $8(11.8 \%)$ & $207(12.1 \%)$ & $90(12.3 \%)$ & & \\
\hline Other & $11(16.2 \%)$ & $135(7.91 \%)$ & $29(3.95 \%)$ & & \\
\hline Unclear/unknown & $5(7.35 \%)$ & 67 (3.93\%) & $37(5.04 \%)$ & & \\
\hline
\end{tabular}

0.7432509

176

177

178 Table 2: Multivariable Model Resuslts

\begin{tabular}{lc|cc|cc}
\hline & \multicolumn{2}{|c|}{ Pain Severity (Worst 24 Hours) } & \multicolumn{2}{|c}{ Pain Severity (Least 24 Hours) } \\
& & Estimate $\mathbf{( 9 5 \% ~ C I )}$ & P-Value & Estimate (95\% CI) & P-Valt \\
\hline BMI & Underweight & $0.284(-0.315,0.884)$ & 0.353 & $0.667(-0.049,1.383)$ & $0.06 \varepsilon$
\end{tabular}




\begin{tabular}{|c|c|c|c|c|}
\hline $\begin{array}{r}\text { ref=Normal } \\
\text { Weight/Overweight } \\
\text { Obese }\end{array}$ & $0.354(0.139,0.569)$ & 0.001 & $0.556(0.301,0.811)$ & $0.00 \mathrm{c}$ \\
\hline Age & $0.000(-0.006,0.006)$ & 0.936 & $-0.002(-0.009,0.005)$ & $0.54 \mathrm{E}$ \\
\hline Pain procedure within $\mathbf{4 5}$ days prior & $0.011(-0.232,0.253)$ & 0.93 & $-0.157(-0.445,0.132)$ & $0.28 i$ \\
\hline $\begin{array}{l}\text { Opioid prescription within } 45 \text { days } \\
\text { prior }\end{array}$ & $0.715(0.517,0.914)$ & $<0.001$ & $0.655(0.419,0.890)$ & $0.00 \mathrm{c}$ \\
\hline \multirow{6}{*}{$\begin{array}{r}\text { ref=Muskuloskeletal } \\
\text { Neuropathic } \\
\text { Other } \\
\text { Unclear/unknown } \\
\text { Worst Pain }\end{array}$} & $-0.004(-0.304,0.296)$ & 0.978 & $-0.127(-0.483,0.230)$ & $0.48 t$ \\
\hline & $0.061(-0.326,0.448)$ & 0.758 & $-0.491(-0.949,-0.32)$ & 0.36 \\
\hline & $-0.290(-0.764,0.185)$ & 0.232 & $-0.338(-0.901,0.224)$ & 0.235 \\
\hline & & & 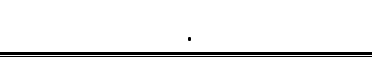 & \\
\hline & \multicolumn{2}{|c|}{ Pain Severity (Average 24 Hours) } & \multicolumn{2}{|c|}{ Pain Severity (Current) } \\
\hline & Estimate $(95 \% \mathrm{Cl})$ & P-Value & Estimate $(95 \% \mathrm{Cl})$ & P-Valt \\
\hline $\begin{array}{r}\text { Underweight } \\
\text { ref=Normal } \\
\text { Weight/Overweight }\end{array}$ & $0.437(-0.146,1.020)$ & 0.142 & $0.748(0.061,1.434)$ & $0.03:$ \\
\hline Obese & $0.382((0.171,0.592)$ & 0.000 & $0.625(0.376,0.874)$ & 0.25 \\
\hline Age & $0.003(-0.003,0.008)$ & 0.391 & $-0.008(-0.015,-0.001)$ & 0.25 \\
\hline Pain procedure within 45 days prior & $-0.118(-0.358,0.121)$ & 0.332 & $-0.079(-0.360,0.202)$ & $0.58 c$ \\
\hline $\begin{array}{l}\text { Opioid prescription within } 45 \text { days } \\
\text { prior }\end{array}$ & $0.595(0.400,0.790)$ & 0.000 & $0.748(0.519,0.978)$ & 0.006 \\
\hline ref=Muskuloskeletal & & & & \\
\hline Neuropathic & $-0.048(-0.341,0.245)$ & 0.748 & $-0.104(-0.450,0.243)$ & $0.55 \xi$ \\
\hline Other & $-0.149(-0.530,0.232)$ & 0.443 & $-0.467(-0.914,-0.020)$ & 0.04 \\
\hline Unclear/unknown & $-0.228(-0.690,0.234)$ & 0.333 & $-0.312(-0.857,0.234)$ & 0.26 \\
\hline \multirow[t]{2}{*}{ Worst Pain } & & & & \\
\hline & $\begin{array}{l}\text { Pain Interfere } \\
\text { Estimate }(95 \% \mathrm{Cl})\end{array}$ & P-Value & & \\
\hline $\begin{array}{r}\text { Underweight } \\
\text { ref=Normal } \\
\text { Weight/Overweight }\end{array}$ & $0.319(-0.163,0.801)$ & 0.194 & & \\
\hline Obese & $0.276(0.104,0.449)$ & 0.002 & & \\
\hline Age & $-0.017(-0.022,-0.013)$ & 0.000 & & \\
\hline Pain procedure within 45 days prior & $-0.054(-0.248,0.141)$ & 0.588 & & \\
\hline $\begin{array}{l}\text { Opioid prescription within } 45 \text { days } \\
\text { prior }\end{array}$ & $0.425(0.263,0.586)$ & 0.000 & & \\
\hline $\begin{array}{r}\text { ref=Muskuloskeletal } \\
\text { Neuropathic }\end{array}$ & $-0.151(-0.392,0.091)$ & 0.222 & & \\
\hline Other & $-0.342(-0.080,0.681)$ & 0.030 & & \\
\hline Unclear/unknown & $0.300(0.657,0.721)$ & 0.122 & & \\
\hline Worst Pain & $0.689(0.657,0.721)$ & 0.000 & & \\
\hline
\end{tabular}




\section{DISCUSSION}

\section{Pain Prevelance}

182 Our study showed that pain clinic patients with obesity experience higher pain severity and pain 183 interference scores than normal weight and overweight patients. Our findings corroborate prior

184 literature that shows that obesity is a risk factor for chronic pain ${ }^{26-29}$, and demonstrates that 185 obesity is an independent risk factor for experiencing more pain severity and pain that may 186 interfere with patients' daily function. Heim et al. reported that in a population of older adults,

187 obese patients were more likely to develop pain, and that the frequency of pain increased more 188 drastically with increased BMI, especially for women ${ }^{30}$. Their study found that, regardless of 189 weight changes, someone with a higher BMI is more likely to longitudinally develop chronic 190 pain ${ }^{30}$.

\section{Pain Severity}

193 Our study found that obesity was related to pain severity. Patients' rating of worst pain in the last 19424 hours was statistically significant, with increased pain severity found in obese patients 195 compared to the normal and over- weight patients. Obesity as a risk factor for pain severity has

196 been found in many other studies, ranging from adolescents to geriatric populations ${ }^{31 ; 32}$. Chronic 197 pain development in an obese population, particularly morbidly obese (BMI>35), after a motor 198 vehicle accident had a significant effect on increasing pain severity during multiple follow-up 199 visits within a year ${ }^{22}$.

201 However, some studies have disputed the relationship between pain severity and obesity ${ }^{19 ; 33}$.

202 Taspinar et al. did not find obesity to influence pain severity for university students with 
medRxiv preprint doi: https://doi.org/10.1101/2020.03.02.20027425; this version posted March 3, 2020. The copyright holder for this preprint (which was not certified by peer review) is the author/funder, who has granted medRxiv a license to display the preprint in perpetuity.

All rights reserved. No reuse allowed without permission.

203

204

205

206

207

208

209

210

211

212

213

214

215

216

217

218

219

220

221

222 In our study, obese patients had higher pain interference than normal weight patients.This

223 follows previous trends finding that obese patients have a higher frequency of pain interference

224 and more severe disability from pain ${ }^{19 ; 29 ; 32 ; 36}$. Only one study found obesity to be independent of

225 pain interference scores ${ }^{18}$.

nonspecific back pain. However, this study included only university students, which limits its generalizability to the wider chronic pain population, which includes patients of a larger age range.

Looking at the underweight population, the literature agrees with our finding of increased current pain severity in the underweight population compared to the normal group ${ }^{34}$. Previously, this has also influenced the prescription of opioid medications for pain relief, specifically in cancer populations, but the true clinical relevance has yet to be determined.

\section{Pain Interference}

Pain severity is related to pain interference, as it is not unexpected that higher levels of pain intensity would have more drastic effects on functioning ${ }^{5}$. In our study, pain interference scores increased with increased ratings of worst pain in the last 24 hours. Pain severity and frequency has been shown to directly predict pain interference and quality of life ${ }^{35-37}$. Of note, our findings contradict with several studies that did not find an association between pain severity and pain interference ${ }^{19}$. This finding could be due to a threshold effect that occurs where low levels of pain intensity are not associated with functional interference and where higher levels of pain intensity increase the probability of higher levels of pain interference in a nonlinear fashion ${ }^{5-7}$. 
227 While these findings are statistically significant, clinical implication has yet to be determined 228 within this research. Previous literature has speculated that at least a $30 \%$ change from baseline 229 on the BPI is required for an impacted quality of life ${ }^{38-40}$.

\section{Opioid Use}

232 Pain experience is also altered by opioid use, which is commonly prescribed for pain

233 management. Opioid usage was statistically significant between the three BMI categories for

234 both IR and ER medication prescription 45 days prior to the visit. IR medication prescription was

235 more commonly used within all three BMI groups compared to ER medication, with underweight and

236 overweight patients having increased prescriptions compared to the normal weight group. In

237 multivariable modelling, opioid usage was significantly associated with higher pain severity and

238 pain interference. The increase in pain severity and interference increasing with opioid use is

239 unique to our study. A previous study found that opioid medications had no statistically

240 significant difference between BMI (obese or not obese), but opioid use did relate to an increase

241 in pain interference ${ }^{18}$. Provider prescriptions of non-steroidal anti-inflammatory drugs used to

242 treat pain found that they are higher amongst obese patients ${ }^{16 ; 17}$. Similar to our studies, previous

243 research analyzing the use of opioids and obesity within the context of pain are often limited in a

244 cross-sectional setting due to the unknown timeline of pain characteristics and opioid

245 prescriptions, thus only being able to examine correlation and not causation.

247 Limitations

248 Our study is limited by retrospective data, multi-institutional data collected primarily from 
medRxiv preprint doi: https://doi.org/10.1101/2020.03.02.20027425; this version posted March 3, 2020. The copyright holder for this preprint (which was not certified by peer review) is the author/funder, who has granted medRxiv a license to display the preprint in perpetuity.

All rights reserved. No reuse allowed without permission.

249

250

251

252

253

254

255

256

257

258 259 ignored.
261

262

263

264

265

266

267

268

269 category ${ }^{28}$.

tertiary care centers, and the high prevalence of musculoskeletal pain in our population. Seventyseven percent of all participants in this study had a diagnosis of musculoskeletal pain, and $79 \%$ of obese participants diagnosed with that as well, being only slightly higher than the normal and overweight category (76.0\%) and significantly higher than the underweight group (64.7\%). Previous literature often restricted cohort populations to those with specific types of pain, like musculoskeletal, since its development has been more easily associated with obesity ${ }^{31 ; 32 ; 41}$. Musculoskeletal pain has also been connected with more pain locations, which is further increased within an obese population ${ }^{32 ; 41}$. While a diagnosis of musculoskeletal pain may influence obesity and pain severity scores, it is an extremely prevalent pain diagnosis with clinical implications in both our population and the general population, and thus could not be

Our study was also limited by the categorization of weight. For our study, obesity was defined as anyone with a BMI greater than or equal to 30. Further stratification of this obese category has shown trends that indicate greater pain in the severely obese. For McCarthy et al., the severely obese, or those with a BMI of at least 35, were associated with four times the probability of having chronic pain compared to normal patients, whereas those with BMI=30-34.99 were only twice as likely ${ }^{32}$. This stratification more drastically shows the impact that obesity poses on the experience of chronic pain. Deyo et al. also showed that for those in the top $20 \%$, the prevalence of pain has been found to be significantly higher than those in the bottom $20 \%$ of the obese 
medRxiv preprint doi: https://doi.org/10.1101/2020.03.02.20027425; this version posted March 3, 2020. The copyright holder for this preprint (which was not certified by peer review) is the author/funder, who has granted medRxiv a license to display the preprint in perpetuity.

All rights reserved. No reuse allowed without permission.

271 Our study only included patients that visited the outpatient pain clinics included in The Registry

272 at least once with BMI information and a diagnosis for the encounter. The survey data analyzed

273 was that of the first survey in the registry for each patient. While the first available BMI value

274 was used as well, this did not consistently align with the first full survey dataset since patients

275 often had multiple pain clinic encounters. By identifying patients retrospectively, we weren't

276 able to follow their progress over more visits longitudinally. In addition, while The Registry is a

277 multi-site database, it gathers information solely from New York City-based sites, which could

278 limit generalizability of our results.

279

280

In addition, our study was not able to capture the prevalence of psychiatric comorbidities within our chronic pain population. Many other studies have found that this dramatically impacts both obesity and pain, often increasing the likelihood or severity of both ${ }^{9-11 ; 26 ; 27 ; 32 ; 42 ; 43}$. Further research is warranted to assess the role of psychiatric comorbidities on pain interference and severity within a chronic pain population, especially as it may influence management choices and clinical prognosis.

\section{Conclusions}

288 Our study demonstrated that pain severity and interference is impacted by obesity and opioid 289 use. The management of chronic pain is multifaceted and complex, particularly in the obese 290 chronic pain population. Our study suggests that these patients' chronic pain is characterized not 291 only by higher pain severity, but also greater interference with activities of daily living. Our 292 findings suggest that counseling patients about their BMI, health maintenance, and setting 293 reasonable expectations in regards to physical functioning and prognosis may improve their pain 
medRxiv preprint doi: https://doi.org/10.1101/2020.03.02.20027425; this version posted March 3, 2020. The copyright holder for this preprint (which was not certified by peer review) is the author/funder, who has granted medRxiv a license to display the preprint in perpetuity. All rights reserved. No reuse allowed without permission.

294 management treatment in terms of lessening their pain severity and pain interference. Further

295 prospective research is warranted to understand the relationship between reducing BMI and pain

296 interference scores.

297

298

299 
medRxiv preprint doi: https://doi.org/10.1101/2020.03.02.20027425; this version posted March 3, 2020. The copyright holder for this preprint

(which was not certified by peer review) is the author/funder, who has granted medRxiv a license to display the preprint in perpetuity.

All rights reserved. No reuse allowed without permission.

300 ACKNOWLEDGEMENTS

301 We would like to thank the Weill Cornell Medicine Department of Anesthesiology for their

302 support. 
medRxiv preprint doi: https://doi.org/10.1101/2020.03.02.20027425; this version posted March 3, 2020. The copyright holder for this preprint (which was not certified by peer review) is the author/funder, who has granted medRxiv a license to display the preprint in perpetuity.

All rights reserved. No reuse allowed without permission.

\section{REFERENCES}

1. Gaskin DJ, Richard P. The economic costs of pain in the united states. J Pain 2012;13:715-24.

2. Relieving pain in america: A blueprint for transforming prevention, care, education, and research. Mil Med 2016;181:397-9.

3. Nahin RL. Estimates of pain prevalence and severity in adults: United states, 2012. J Pain 2015;16:769-80.

4. Daubresse $\mathrm{M}, \mathrm{Chang} \mathrm{HY}, \mathrm{Yu} \mathrm{Y}$ et al. Ambulatory diagnosis and treatment of nonmalignant pain in the united states, 2000-2010. Med Care 2013;51:870-8.

5. White RS, Jiang J, Hall CB et al. Higher perceived stress scale scores are associated with higher pain intensity and pain interference levels in older adults. J Am Geriatr Soc 2014;62:2350-2356.

6. Jensen MP, Smith DG, Ehde DM, Robinsin LR. Pain site and the effects of amputation pain: Further clarification of the meaning of mild, moderate, and severe pain. Pain 2001;91:317-22.

7. Woo A, Lechner B, Fu T et al. Cut points for mild, moderate, and severe pain among cancer and non-cancer patients: A literature review. Ann Palliat Med 2015;4:176-83.

8. Okifuji A, Hare BD. The association between chronic pain and obesity. J Pain Res 2015;8:399408.

9. Hales CM, Carroll MD, Fryar CD, Ogden CL. Prevalence of obesity among adults and youth: United states, 2015-2016. NCHS Data Brief 2017:1-8.

10. Arnstein P, Caudill M, Mandle CL, Norris A, Beasley R. Self efficacy as a mediator of the relationship between pain intensity, disability and depression in chronic pain patients. Pain 1999;80:483-91.

11. Zdziarski LA, Wasser JG, Vincent HK. Chronic pain management in the obese patient: A focused review of key challenges and potential exercise solutions. J Pain Res 2015;8:63-77.

12. Hitt HC, McMillen RC, Thornton-Neaves T, Koch K, Cosby AG. Comorbidity of obesity and pain in a general population: Results from the southern pain prevalence study. J Pain 2007;8:430-6.

13. Briggs MS, Givens DL, Schmitt LC, Taylor CA. Relations of c-reactive protein and obesity to the prevalence and the odds of reporting low back pain. Arch Phys Med Rehabil 2013;94:745-52.

14. Schaible HG, von Banchet GS, Boettger MK et al. The role of proinflammatory cytokines in the generation and maintenance of joint pain. Ann N Y Acad Sci 2010;1193:60-9.

15. Sommer $\mathrm{C}$, Kress $\mathrm{M}$. Recent findings on how proinflammatory cytokines cause pain: Peripheral mechanisms in inflammatory and neuropathic hyperalgesia. Neurosci Lett 2004;361:184-7.

16. Antonov KI, Isacson DG. Prescription and nonprescription analgesic use in sweden. Ann Pharmacother 1998;32:485-94.

17. Counterweight Project T. The impact of obesity on drug prescribing in primary care. $\mathrm{Br} J \mathrm{Gen}$ Pract 2005;55:743-9.

18. Anastas T, Colpitts K, Ziadni M, Darnall BD, Wilson AC. Characterizing chronic pain in late adolescence and early adulthood: Prescription opioids, marijuana use, obesity, and predictors for greater pain interference. Pain reports 2018;3:e700.

19. Marcus DA. Obesity and the impact of chronic pain. The Clinical journal of pain 2004;20:186-91.

20. Eslami V, Katz MJ, White RS et al. Pain intensity and pain interference in older adults: Role of gender, obesity and high-sensitivity c-reactive protein. Gerontology 2017;63:3-12.

21. Pazzianotto-Forti EM, Sgariboldi D, Rasera I, Jr., Reid WD. Impact of pain in overweight to morbidly obese women: Preliminary findings of a cross-sectional study. Physiotherapy 2018;104:417-423.

22. Mauck MC, Hu J, Sefton $\mathrm{C}$ et al. Obesity increases the risk of chronic pain development after motor vehicle collision. Pain 2019;160:670-675. 
medRxiv preprint doi: https://doi.org/10.1101/2020.03.02.20027425; this version posted March 3, 2020. The copyright holder for this preprint (which was not certified by peer review) is the author/funder, who has granted medRxiv a license to display the preprint in perpetuity.

All rights reserved. No reuse allowed without permission.

23. Mehta N, Inturrisi CE, Horn SD, Witkin LR. Using chronic pain outcomes data to improve outcomes. Anesthesiology Clin 2016;34:395-408.

24. Cleeland CS, Ryan KM. Pain assessment: Global use of the brief pain inventory. Ann Acad Med Singapore 1994;23:129-38.

25. Team RC. R: A language and environment for statistical computing. . R Foundation for Statistical Computing 2019;Vienna, Austria.

26. Shi Y, Hooten WM, Roberts RO, Warner DO. Modifiable risk factors for incidence of pain in older adults. Pain 2010;151:366-71.

27. Ray L, Lipton RB, Zimmerman ME, Katz MJ, Derby CA. Mechanisms of association between obesity and chronic pain in the elderly. Pain 2011;152:53-9.

28. Deyo RA, Bass JE. Lifestyle and low-back pain. The influence of smoking and obesity. Spine 1989;14:501-6.

29. Rubin DI. Epidemiology and risk factors for spine pain. Neurologic clinics 2007;25:353-71.

30. Heim N, Snijder MB, Deeg DJ, Seidell JC, Visser M. Obesity in older adults is associated with an increased prevalence and incidence of pain. Obesity (Silver Spring, Md) 2008;16:2510-7.

31. Deere KC, Clinch J, Holliday $\mathrm{K}$ et al. Obesity is a risk factor for musculoskeletal pain in adolescents: Findings from a population-based cohort. Pain 2012;153:1932-8.

32. McCarthy LH, Bigal ME, Katz M, Derby C, Lipton RB. Chronic pain and obesity in elderly people: Results from the einstein aging study. J Am Geriatr Soc 2009;57:115-9.

33. Taspinar F, Taspinar B, Cavlak U, Celik E. Determining the pain-affecting factors of university students with nonspecific low back pain. Journal of physical therapy science 2013;25:1561-4.

34. Moryl N, Bokhari A, Griffo Y et al. Does transdermal fentanyl work in patients with low bmi? Patient-reported outcomes of pain and percent pain relief in cancer patients on transdermal fentanyl. Cancer medicine 2019;8:7516-7522.

35. Hunfeld JA, Perquin CW, Duivenvoorden HJ et al. Chronic pain and its impact on quality of life in adolescents and their families. Journal of pediatric psychology 2001;26:145-53.

36. Lamb SE, Guralnik JM, Buchner DM et al. Factors that modify the association between knee pain and mobility limitation in older women: The women's health and aging study. Annals of the rheumatic diseases 2000;59:331-7.

37. Thomas JG, Pavlovic J, Lipton RB et al. Ecological momentary assessment of the relationship between headache pain intensity and pain interference in women with migraine and obesity. Cephalalgia : an international journal of headache 2016;36:1228-1237.

38. Atkinson TM, Rosenfeld BD, Sit L et al. Using confirmatory factor analysis to evaluate construct validity of the brief pain inventory (bpi). Journal of pain and symptom management 2011;41:558-65.

39. Hoffman DL, Sadosky A, Dukes EM, Alvir J. How do changes in pain severity levels correspond to changes in health status and function in patients with painful diabetic peripheral neuropathy? Pain 2010;149:194-201.

40. Mease PJ, Spaeth M, Clauw DJ et al. Estimation of minimum clinically important difference for pain in fibromyalgia. Arthritis care \& research 2011;63:821-6.

41. Adamson J, Ebrahim S, Dieppe P, Hunt K. Prevalence and risk factors for joint pain among men and women in the west of scotland twenty-07 study. Annals of the rheumatic diseases 2006;65:520-4.

42. Jordan KP, Thomas E, Peat G, Wilkie R, Croft P. Social risks for disabling pain in older people: A prospective study of individual and area characteristics. Pain 2008;137:652-61.

43. Johannes CB, Le TK, Zhou X, Johnston JA, Dworkin RH. The prevalence of chronic pain in united states adults: Results of an internet-based survey. J Pain 2010;11:1230-9. 
medRxiv preprint doi: https://doi.org/10.1101/2020.03.02.20027425; this version posted March 3, 2020. The copyright holder for this preprint (which was not certified by peer review) is the author/funder, who has granted medRxiv a license to display the preprint in perpetuity.

All rights reserved. No reuse allowed without permission. 